REGULAR ARTICLE

\title{
DETERMINANTS OF RURAL HOUSEHOLD SAVINGS BEHAVIOUR: THE CASE OF TOMATO FARMERS IN GHANA
}

\author{
Daniel AIDOO-MENSAH
}

\author{
Address: \\ Faculty of Applied Sciences, Methodist University College Ghana, P. O. Box 195 Wenchi - Brong Ahafo Region \\ E-mail: danielaidoomensah@gmail.com
}

\begin{abstract}
Much as savings plays an important role in economic development process, it has been neglected very much in favour of credit in rural communities particularly in developing countries. Against this backdrop the study sought to determine tomato farmers' capacity to save and also to examine the determinants of savings among this group of farmers in three regions of Ghana namely Ashanti, Brong Ahafo and Upper East regions. Data was collected with the aid of structured questionnaire. Descriptive statistics and Ordinary Least Squares (OLS), were used to analyse the data. Empirical results based on four models of the savings functions advocated by Keynes, Klein and Landau showed the marginal propensity to save (MPS) of the respondents to be $0.88(88 \%)$, indicating a relatively high levels of savings among the respondents. This runs counter to Keynes' assertion that the equalization of income distribution increases aggregate consumption, and hence, reduces savings. The study also established the hypothesis of non-linearity between savings and income among the respondents. This implies that due to lack of permanent income sources among rural dwellers, they tend to consume less of their income in order to save more for the "rainy day". The results of the study have demonstrated that rural households particularly tomato farmers have the capacity to save which is indicated by their relatively high marginal propensity to save of $88 \%$. This finding makes a convincing case for financial intermediaries to extend the needed financial services to rural households.
\end{abstract}

Keywords: Savings, Marginal propensity, Tomato farmers, Income, Ghana JEL: Q12, C21, D14

\section{INTRODUCTION}

Savings behaviour has variously been explained as an understanding of how people save in a country in order to realize supply of funds for investment (Salam and Kulsum, 2002). It is fundamentally underscored by the combination of perceptions of future needs, a saving plan and a saving action (Thung $\boldsymbol{e t}$ al., 2012). The importance of savings behaviour becomes more apparent especially in developing countries where economic fluctuations coupled with climatic risks result in significant income variations. This situation may be exacerbated by restricted social coverage as well as poorly developed credit and insurance markets. Under such circumstances, households' savings becomes crucial to provide the needed insurance against economic and social shocks (Abdelkhalek et al., 2010). Therefore, a better understanding of the dynamics of the savings behaviour at the household level will help in the formulation of appropriate policies for savings mobilisation, thereby improving upon local capital formation capacity to enhance national development.

Ghana has been observed to be the second largest importer of tomato paste after Germany. The nation imports several tonnes of tomato and tomato products into the country, consuming an average of 25,000 tonnes of tomato paste in a year at a total cost of about \$25 million dollars (Yeboah, 2011). In Ghana, the focus of the efforts by various stakeholders in the tomato industry geared towards finding "lasting" solutions to the myriads of problems associated with tomato production has mostly been considered from agronomic perspective (AidooMensah, 2018). However, the challenges of the tomato industry persist in spite of the many solutions proposed by agronomists and allied scientists. Thus, the need to look beyond the agronomic issues to determine the inability of farmers of such an important crop to sustain their production activities.

Hence, the paper which brings to the fore the fact that these farmers' quest for survival now and into the future in today's ever-changing and challenging environment of economic development hinges not only on agronomic issues but also on their ability to sustain their production activities through their savings. In Ghana, this is one of most commonly produced and consumed vegetable (Sinnadurai, 1973; Chagomoka et al., 2015) and the activities of the farmers of this all important crop may be scattered throughout the nation but more concentrated in the study areas.

\section{MOTIVES FOR SAVINGS}

Much as the socio-economic benefits accruing from savings are varied, so also are the motives or reasons underlying individuals' savings decisions (AidooMensah, 2017). This is not unexpected as research in psychology has identified a hierarchy of saving motives ranging from the more concrete or immediate goals (like 
consumption), through intermediate goals (like security needs, retirement, debt avoidance and precaution) to the more abstract goals of self-esteem and self-gratification (Canova, Rattazi and Webley, 2005). Among the early economists to identify savings motives, was Keynes (1936) whose eight savings motives listed below have withstood the test of time:

1. Precaution: Setting aside for unexpected circumstances.

2. Foresight: Meeting anticipated future needs.

3. Calculation: Earning interest.

4. Improvement: Increasing a standard of living over time.

5. Independence: Needing to feel self-sufficient and in control.

6. Enterprise: Investing money into business.

7. Pride: Leaving money to heirs.

8. Avarice or miserliness: Being greedy or tight-fisted.

To these motives suggested by Keynes (1936), Browning and Lusardi (1996) added a ninth one, that is, to accumulate deposits (savings) to buy houses, cars and other durables, termed as the down payment motive. Katona (1975) offered six more general motives for saving as follows: (1) for emergencies, (2) to have funds on reserve for necessities, (3) for retirement or old age, (4) for children's needs, (5) to buy a house or durable goods and (6) for holidays.

In the opinion of Fisher and Anong (2012) these motives may not necessarily be mutually exclusive but rather complementary. According to Browning and Lusardi (1996), there is considerable heterogeneity among the motives for saving. In other words, it is unlikely that a single motive will suffice for all members of a population at any given time or even for the same person over a long stretch of time (Aidoo-Mensah, 2017).

\section{Factors Influencing Savings Behaviour}

Although available evidence according to Alamgir (1976), does not permit any generalization about savings habits in terms of specifying a precise functional form and the variables to be included, it is however, maintained that savings habits are significantly influenced by certain socio-economic and demographic characteristics, cultural and physical variables as well as institutional factors. It is therefore imperative to understand and evaluate the relevant significance of these factors (determinants) especially with reference to their applications in studies relating to farm households in developing countries.

\section{Household Demographic and Socio-economic} Characteristics

It has long been established that size of household, age structure and other demographic as well as socioeconomic characteristics affect household savings habits (Snyder, 1974), hence their importance for empirical studies on analytical grounds (Leff, 1969). The Life Cycle Hypothesis first proposed by Modigliani and Brumberg (1954) and later by Ando and Modigliani (1963) incorporates various demographic and socio-economic characteristics as way of explaining consumption and savings behaviour of individuals or households. Empirically, this hypothesis is tested by introducing such demographic characteristics as age of the household head, the dependency ratio and income into the analytic framework used for explaining savings habits of rural households. Among household demographic and socioeconomic characteristics underlying rural savings habits include the following:

\section{Gender of Household Head}

Empirical evidence points to the fact that the economic well-being and savings behaviours of men and women differ significantly (Fisher, 2010). Women particularly those in most developing countries have been found to possess lower levels of wealth and have significantly lower earnings than men (IMF, 2015). In rural areas of South Saharan Africa for instance, women's ability to obtain assets is governed by family and community norms, which traditionally have favoured men to the detriment of women (Kame ri-Mbote, 2005). In addition, the legal systems at the macro level in different countries determine how much control women can have over assets (Chowa, 2006).

Even though much information has been obtained on the differences in earnings, risk aversion, investment behaviours, and level of wealth among the sexes, little is known about how the factors related to general saving behaviours may differ between men and women (Fisher, 2010). However, it has been found that women live as many as five more years than men in retirement as a result of having longer life expectancies (Gottschalck, 2008). Moreover, it has been reported that women invest their financial resources more conservatively and are, in general, more risk averse than men (Bajtelsmitans VanDerhei, 1997; Yuh and Hanna, 1997). Various studies have also shown that women have lower rates of involvement in retirement plans as compared with men (Sung, 1997) and are more likely to be found in poverty during retirement (Pearce, 1989).

In spite of these shortcomings relating to the female gender as far as financial issues are concerned and despite the importance of saving in regards to the financial security of households, relatively few studies have examined whether there are gender differences in saving (spending less than income) at the household level (Fisher, 2010). However, Chowa (1996) has reported that women save better than men when they have the opportunity to save.

\section{Age Structure of Household}

The life cycle hypothesis defines the age between the consumption plans of an individual and his/her present earnings and expectations concerning future income, as he or she passes from childhood, through the work participating years, into retirement and the eventual demise of the individual (Spio and Groenewald, 1996). This implies that household savings are highest during the working years of the head and when income declines during retirement years (Saint-Pierre, 1996), the household draws from their previous savings to maintain the standard of living (Wilson, 2000). Thus, savings is needed by the household to reallocate resources over time thereby smoothing consumption over their life span especially during the retirement age of the household head. Many empirical studies have noted some degree of correlation between the age structure of the household and the savings-income relationships of households.

The first independent test of the hypothesis was done by Fisher (1956), who conducted a cross section analysis 
of savings of some 2000 households. Data were subclassified by age of head of household and by socioeconomic group as a proxy for income stability. Current income and liquid asset holdings were used as independent variables. There was evidence of peaking of marginal propensities to save in higher age working groups and a rundown of assets in retirement years. Negative savings were also exhibited in the youngest age groups (Spio and Groenewald, 1996). The most searching analysis of the hypothesis was carried by Kelley and Williamson (1968). They found that income per family member declines up to the age group 40-49 and stabilises or rises only slightly thereafter.

\section{Household Size}

Household size has relevant implications for household purchasing and spending behaviour (Jerome and Perreault, 1991), vis-à-vis, savings-income relationships. All things being equal, it is assumed that households with large family sizes spend more on goods and services than households with small family sizes. Larger family size is therefore found to be associated with greater budget shares devoted to housing and education and all things being equal, this has the tendency to deprive such households enough resources to save and this in most cases results in cyclical poverty (Arthur, 2005). This is more pronounced in rural areas where food and other basic needs consumption, absorb up to 80-90per cent of the household budget. However, in a life cycle context, children may add to the household's productive resources by providing more labour and probably more assets (Chernichovsky, 1978) but in general, household size is supposed to reflect the expenditure pull on household income and the usual expectation is that it will negatively correlate with savings (Alamgir, 1976).

\section{Marital Status of Household Head}

Studies indicate that being married has a large effect on reducing the risk of poverty and is associated with a higher probability of attaining affluence over the life course when compared with non-marriage. Compared to married couples, unmarried people have also been found to save much lower portions of their income and accumulate fewer assets (Grinstein-Weiss, Zhan and Sherraden, 2004).

From an economic point of view, marriage has several characteristics that may enhance wealth accumulation (Waite, 1995). Grinstein-Weiss et al., (2004) outlined six economic perspectives underlying wealth accumulation vis-à-vis, savings in households where the head is married: First, the total product of a married couple is larger than the sum of the outputs of each produced separately. Second, the institution of marriage entails long-term commitment in which a division of labour enables each spouse to specialize in specific skills and duties. This specialization increases the productivity and the efficiency of the household. Third, economies of scale in consumption suggest that a married couple may achieve the same utility with less combined expenditure than the sum of their individual consumption if living apart. Fourth, the requirements and expectations of married (versus single) life may encourage people to buy a house, save for children's education, and acquire cars and other assets. Fifth, there is persistent evidence that married men earn more than unmarried men. Sixth, the institution of marriage expands one's social network and social support, which may result in additional opportunities and benefits that lead to savings. Finally, married individuals may have access to many benefits such as health and life insurance provided by the spouse's employment which in a way will reduce the pressure on the household income, thereby enhancing the ability to save.

\section{Dependency Ratio}

Age-dependency ratios are a measure of the age structure of the population. They relate the number of individuals that are likely to be "dependent" on the support of others for their daily living - youths and the elderly (that is, the percentage of the population aged 15 years and below together with the percentage of the population aged 65 years and above) to the number of those individuals who are capable of providing such support (OECD, 2007). In defining the dependency ratio, it has been implicitly assumed that the population aged 15 years and below plus 65 years and above adds to household consumption and contributes nothing towards production.

The life cycle model predicts that a relatively large burden of children (and/or the elderly) would cause aggregate savings rates to be relatively small, and that are relatively large size of the older working proportion of the household would reflect a higher aggregate savings rate. The model can therefore be expanded to include the hypothesis of household dependents creating a burden on household savings-income relationships, that is, households provide for the consumption of dependents particularly the younger ones by sacrificing savings in the early stages of household formation and then save at a high rate during the empty-nest stage in order to prepare for retirement (Wilson, 2000). For instance, in an empirical study of 47 countries, Leff (1969) indicated that the dependency rate of the young (those aged 15 and below) and of the old (those aged 65 and above) negatively affected savings rates in those countries. It therefore stands to reason that dependents contribute to consumption but not to production, therefore, imposing a constraint on society's potential for savings.

According to Gedela (2012), the dependency burden on savings is more pronounced in developing countries where 70 percent of the population lives in the rural areas. In these areas, children are considered an asset because of their contribution to household activities and farm operations (Amaza et al., 2009). Thus, the impact of the dependency ratio on household savings can be more meaningfully examined if, instead of putting a restriction on the age of the household member, their earning status is explicitly taken into account.

\section{Educational level of Household head}

The variable educational status of the household is usually defined as the number of years of formal education attained by the household head. It is usually assumed that a high educational status equips one with better financial management, thereby, impacting positively on savings habits. For instance, Solmon (1975) compared the savings rates of different educational groups and found that both the marginal and average propensities to save tend to rise with the number of years of education. Using longitudinal data from the 1983 and 1986 Surveys of Consumer 
Finances from the United States, Avery and Kennickell (1991) reported that as respondent education level increased, wealth increased over the three-year-period. In contrast to the positive relationship between education and savings, Rha, Montalto, and Hanna (2006) found that households having household heads with an advanced degree were significantly less likely to save than other wise similar households where the head had a high school diploma. However, the overall conclusion is that increased level of education of the household head explains a substantial part of the growth of the economic output and increased incomes of households in both developed and developing countries (Johnson, 1990).

\section{Income}

Generally, rural household income has been defined as the sum of the net flow of receipts or earnings from all members of the household from different economic activities during a reference period usually one accounting year (Alamgir, 1976). Such economic activities may include agricultural wages (from crops and livestock; and other related enterprises, non-agricultural wages, remittances, and receipts from property-rentals both in cash and in kind.

Income has been considered the most important factor in the determination of savings not only at the rural household level but at the national level as well. Various empirical studies based on different methodologies conducted in different parts of the world, all found a positive relationship between income and savings (Kodom, 2013). In general, both Keynesian and nonKeynesian savings functions postulate a positive relationship between savings and income. The positive relationship postulated by both models has been confirmed in various empirical studies. For instance, Kudaisi (2013) in her study of West African countries during 1980-2006 confirmed that increase in income has a positive effect on household savings. Similarly, Guma and Bonga-Bonga (2016) in their empirical work among corporate and household savings in South Africa as well as Fisher and Anong (2012) in their study of 3,822 nonretired households in the United States all confirmed that increase income has a positive effect on household savings.

\section{Institutional Arrangements Influencing Savings Behaviour}

One of the shortcomings of the economic theories of savings, according to Beverly (1997) is that they are prejudiced towards individuals and households with higher income. The institutional model of savings underscores the fact that suitable institutional arrangements other than income and preferences may play an important role in promoting savings particularly among rural households (Beverly and Sherraden, 1999). This reinforces the larger message that institutional (either formal or informal) mechanisms play a vital role in any household's decision to save, thus, low saving rates partly stem from a lack of appropriate institutional saving devices, not lack of desire to save on the part of rural households (Armendariz and Morduch, 2005).

A fundamental difference between the institutional model of savings and the traditional neoclassical economic theory is in the way savings are generated. Whereas the traditional economic theory sees savings as a result of individual choices, the institutional model suggests that savings occur in households largely through appropriate institutional arrangements. Thus, effective asset accumulation can be structured and often subsidised through favourable institutional arrangements. Among most households, unstructured savings, which are left over from income minus consumption, are likely to be smaller than asset accumulation generated by institutional arrangements (Grinstein-Weiss et al., 2004).

According to Hussein and Thirlwall (1999), there is no single measure that can capture the institutional determinants of the savings-income relationships of rural households. However, Beverly and Sherraden (1999) proposed four institutional determinants of savings: institutionalized saving mechanisms (access), targeted financial education, attractive saving incentives (e.g., matched savings), and facilitation (e.g., payroll deduction). It is therefore posited that a number of institutional arrangements suitable to the rural household setting can elicit from them favourable savings response. These may include the following:

Locational convenience - Proximity of the service provider to the clients, that is, the distance covered by the rural household in order to access the nearest savings facility (Akaah et al., 1987; Wright, 1999; Bendig et al., 2009).

Cost of transaction, that is, how much it will cost the clients to access the services of the service provider in terms of transportation cost, service charges, and inconveniences if the premises or the office of the service provider is not within a walking distance (Akaah et al., 1987; Wright, 1999; Carpenter and Jensen, 2002; Bendig et al., 2009; Kar and Dash, 2009).

Varied range of financial products or services available to the rural household.

Speed with which services are provided, that is, how fast or how quick the service provider fulfils the financial requirements of the clients, that is, quick and access to savings without a lot of bureaucracy (Robinson, 2001; Mbuthia, 2011).

Simplicity and straightforwardness of transactions this refers to the ease with which the clients can access financial services from the service provider in terms of language used in filling transactions and the level or extent of the use of technical financial terms or jargons as well as services without a lot of bureaucracy (Wright, 1999; Robinson, 2001; Hirschland, 2006; Mbuthia, 2011).

Customer-friendly attitude towards clients - this is necessary because of the westernised perception of formal institutions by rural folks and therefore the tendency that rural clients would be looked down upon by the staff of the financial institutions (Wright, 1999; Robinson, 2001).

Safety or security of savings - how secure the savings of the clients are (Klaehn, Branch and Evans, 2002).

Ability to deposit/save small amounts (Aryeetey and Gockel, 1991).

Flexibility and reliability of service provided.

Convenience of service hours of opening and closing (Beck et al., 2006). 
Savings density - a measure of the number of financial institutions available to the rural households.

Ease and convenience with which one gets access to his/her savings (Rutherford, 1996; Robinson, 2001; Beck et al., 2006)

\section{DATA AND METHODS}

\section{Types and Sources of Data for the Study}

Empirical research into the dynamics of household savings is generally undertaken using either of two methods: the use of aggregate data and the use of primary data (Niculescu-Aron, 2012). This study made use of the second method, that is, the employment of primary data. The employment of primary data for the study is underlined by the fact that exploration of such data can be relied upon to give accurate facts and valuable understandings of household savings. Additionally, the analysis of primary data on savings can be a good source to obtain a wealth of information for policy considerations. Structured questionnaire was administered to obtain information on respondents' income from tomato production, amount received in the form of remittances from relatives and their tomato farm sizes. Moreover, relevant socio-economic and demographic factors such as educational background, gender, household size, distance to the nearest financial service provider and engagement in non-farm activities were obtained.

\section{Sampling Technique}

Number of respondents for the study was obtained by utilizing Bartlett et al., (2001) (Eq. 1).

$n=\frac{Z^{2}(p)(q)}{(E)^{2}}$

Where

$n$ Sample size

$p$ Proportion of people who access financial services/those who have bank account $q$ Proportion of people who do not have to access financial services/those who do not have bank account

$Z$ Number of standard deviation for a chosen confidence interval level

\section{$E$ Allowable margin of error}

In line with the GLSS (5) report which estimated that about $42 \%$ of inhabitants of rural areas have access to financial services (savings account) (GSS, 2008), and assuming a $95 \%$ confidence level and 5\% margin of error, the number of respondents was obtained by:

$n=\frac{1.96^{2} \times 0.42 \times 0.58}{0.05^{2}}=374$

Nevertheless, as a means of capturing the economic multiplicity of the selected regions on an enlarged scale, thereby, ensuring realistic distribution of the respondents within the selected districts, as well as improving the reliability and validity of the results, the sample size was augmented by $60 \%$. Accordingly, the total sample size was approximated to 599 as indicated on Table 1. This was uniformly spread across the selected districts based on the number of households engaged in agricultural production obtained from the 2010 Population and Housing Census. The response rate was $94 \%$, that is, 562 out of the 599 were fit for the analyses.

The sample for the study was carefully chosen using three (3) approaches. The first of these approaches was the purposive selection of the regions, that is, Ashanti, Brong Ahafo and Upper East regions. The second approach was based on purposive selection of two districts from each of the afore-mentioned regions. The third approach involved random selection of respondents for the study and this was done with assistance from Agricultural Extension Agents (AEAs) responsible for the operational areas in each of the selected districts. The choice of the three regions and their respective districts was informed by the level of tomato production as a result of analysis of official statistics from Ministry of Food and Agriculture (MoFA).

Table 1: Selected districts and sample size

\begin{tabular}{|c|c|c|c|c|c|}
\hline Region & Districts & $\begin{array}{l}\text { Number of } \\
\text { households } 1\end{array}$ & $\begin{array}{l}\text { Number of households } \\
\text { engaged in agricultural } \\
\text { production }^{2}\end{array}$ & $\begin{array}{l}\text { Proportion of } \\
\text { households engaged in } \\
\text { agricultural production } \\
(\%)^{3}\end{array}$ & $\begin{array}{l}\text { Sample size } \\
\text { selected from } \\
\text { each district }{ }^{4}\end{array}$ \\
\hline Ashanti & Offinso North & 11,164 & 8,794 & 77 & 61 \\
\hline & $\begin{array}{l}\text { Sekyere } \\
\text { Central }\end{array}$ & 14,632 & 11,764 & 80 & 82 \\
\hline Brong & Wenchi & 19,138 & 12,485 & 65 & 87 \\
\hline Ahafo & $\begin{array}{l}\text { Techiman } \\
\text { North }\end{array}$ & 47,627 & 23,916 & 50 & 166 \\
\hline Upper & Bongo (Vea) & 15,188 & 12,711 & 84 & 88 \\
\hline East & $\begin{array}{l}\text { Kasena- } \\
\text { Nankana East } \\
\text { (Tono) }\end{array}$ & 19,790 & 16,562 & 84 & 115 \\
\hline TOTAL & & 127,539 & 86,232 & & 599 \\
\hline
\end{tabular}

Source: ${ }^{1,2}$ Regional Analytical Report of the 2010 Population and Housing Census, Ghana Statistical Service Statistics; ${ }^{3,4}$ Author's calculation 


\section{Analytical Framework}

According to Keynesian economists, savings represents that part of a person's disposal income earned in a given period, which has not been consumed. That is, savings is algebraically given as the amount left over when a person's expenditure is subtracted from his/her disposable income. The functional relationship between income $(Y)$ and consumption $(C)$ as postulated by Keynes can be expressed as Eq. 2.

$C=\alpha+\beta Y$

Where:

$\alpha$ is autonomous consumption and $\beta$ is the marginal propensity to consume out of income, $Y$.

Given the definition of savings, $S$ as a residual of household consumption (expenditure) from income, it may be symbolically expressed as Eq. 3 .

$S=Y-C$

Combining Equations (2) and (3), Keynesian Savings Functions can be derived as Eq. 4.

$S=-\alpha+(1-\beta) Y$

The negative intercept denotes dis-saving and the coefficient $(1-\beta)$ of income is termed as the marginal propensity to save (MPS). However, the Keynesian savings function in its most commonly used form is linear with a constant MPS, which can be expressed as Eq. 5 .

$S=\beta_{0}+\beta_{1} Y$

Where:

$\beta_{1}$ is the constant MPS. It is assumed that $\beta_{0}<0$ and $0<$ $\beta_{1}<1$ such that as the level of income $(Y)$ rises, average propensity to save $(S / Y)$ will also increase. However, if the intercept, $\beta_{0}$ is positive or $\beta_{1}$ is negative, then average propensity to save (APS) will decrease with increasing income (Mikesell and Zinser, 1973).

The most widely used functional form in analysing household savings behaviour is based on Keynes' Absolute Income Hypothesis whose empirical application is expressed in the linear form as Eq. 6.

$S=\beta_{0}+\beta_{1} Y+\beta_{2} Z$

Where:

$S$ and $Y$ are savings and income respectively and $Z$ is an aggregate of socio-economic variables that underline savings. However, many empirical applications of the savings function have proved that though savings increases with increases in income, the relationship is not necessarily linear (Bofinger and Scheuermeyer, 2014). Equation (6) may therefore be deemed as unsuitable to analyse the respondents' savings behaviour. One possible way of introducing nonlinearity in the savings function is the quadratic Keynesian function given as Eq. 7.

$S=\beta_{0}+\beta_{1} Y+\beta_{2} Y^{2}+\beta_{3} Z$
However, the possibility of encountering problems with heteroscedasticity of the estimates of the coefficients of $\beta_{1}, \beta_{2}$ and $\beta_{3}$ make Equation (7) equally unsuitable. One way according to Burney and Khan (1992), to avoid the problem of heteroscedasticity is to express savings as a percentage of income as given by Eq. 8 .

$\frac{S}{Y}=\beta_{0}+\beta_{1} Y+\beta_{2}(1 / Y)+\beta_{3} Z$

Klein (1954) introduced nonlinearity in the savings function by suggesting the functional form of Eq. 9.

$S / Y=\beta_{0}+\beta_{1} \log Y+\beta_{3} Z$

A positive and statistically significant coefficient of $\beta_{1}$ in Equation (8) and $\beta_{1}$ in Equation (9) would support the traditional Keynesian wisdom that equalization of income distribution increases aggregate consumption (Burney and Khan, 1992). In order to test the hypothesis of linear versus nonlinear relationship between savings and income, Landau (1971) suggested the functional form of Eq. 10.

$S / Y=\beta_{0}+\beta_{1} Y+\beta_{2}(\log Y)^{2}+\beta_{3}$

A positive and statistically significant coefficient of $\beta_{2}$ would support the hypothesis of nonlinearity (Burney and Khan, 1992).

Four models of the savings function (Model 1-4) were estimated using ordinary least squares (OLS) method:

$S=\beta_{0}+\beta_{1} Y+\beta_{2} Z$

(MODEL 1)

$\frac{S}{Y}=\beta_{0}+\beta_{1}(1 / Y)+\beta_{2} Z$

(MODEL 2)

$S / Y=\beta_{0}+\beta_{1} \log Y+\beta_{2} Z$

(MODEL 3)

$S / Y=\beta_{0}+\beta_{1}(\log Y)^{2}+\beta_{2} Z$

(MODEL 4)

Where:

$S$ and $Y$ are savings and income respectively and $Z$ is an aggregate of demographic and socio-economic variables that underline savings. Model 1 is the linear functional form based on Keynes' Absolute Income Hypothesis. Model 2 is a modified version of the non-linear Keynesian functional form suggested by Burney and Khan (1992). Models 3 and 4 also non-linear functional forms propounded by Klein (1954) and Landau (1971) respectively with some modifications on the one suggested by Landau.

\section{RESULTS AND DISCUSSION}

Production of tomato in the three regions is in the domain of males $(98.1 \%$ ) (Table 2). This to some extent has been attributed to the labour requirement of tomato cultivation which tends to be very high as well as the intensive use of agro-chemicals with its concomitant health hazards (Mensah, Konadu and Agyare, 2013), making this sector of agricultural production less attractive to females. 
Table 2: Demographic characteristics of respondents

\begin{tabular}{|c|c|c|c|c|c|c|c|c|}
\hline \multirow[t]{2}{*}{ Variable } & \multicolumn{2}{|c|}{$\begin{array}{l}\text { Ashanti } \\
\text { Region } \\
(\mathrm{N}=134)\end{array}$} & \multicolumn{2}{|c|}{$\begin{array}{l}\text { Brong Ahafo } \\
\text { Region } \\
(\mathrm{N}=237)\end{array}$} & \multicolumn{2}{|c|}{$\begin{array}{l}\text { Upper East } \\
\text { Region } \\
(\mathrm{N}=191)\end{array}$} & \multicolumn{2}{|c|}{$\begin{array}{l}\text { All households } \\
(\mathrm{N}=562)\end{array}$} \\
\hline & $\mathrm{N}$ & $\%$ & $\mathrm{~N}$ & $\%$ & $\mathrm{~N}$ & $\%$ & $\mathrm{~N}$ & $\%$ \\
\hline \multicolumn{9}{|c|}{ Gender of Respondents } \\
\hline Male & 98 & 73.1 & 204 & 86.1 & 148 & 77.5 & 450 & 80.1 \\
\hline Female & 36 & 26.9 & 33 & 13.9 & 43 & 22.5 & 112 & 19.9 \\
\hline \multicolumn{9}{|l|}{ Age Category } \\
\hline$<30$ & 13 & 10 & 63 & 27 & 28 & 15 & 104 & 19 \\
\hline $30-65$ & 114 & 85 & 161 & 68 & 162 & 85 & 437 & 78 \\
\hline$>65$ & 7 & 5 & 13 & 5 & 1 & 1 & 21 & 4 \\
\hline \multicolumn{9}{|c|}{ Highest level of formal education } \\
\hline None & 30 & 22.4 & 39 & 16.5 & 73 & 38.2 & 142 & 25.3 \\
\hline Primary & 26 & 19.4 & 27 & 11.4 & 74 & 38.7 & 127 & 22.6 \\
\hline MSLC & 41 & 30.6 & 75 & 31.6 & 1 & 0.5 & 117 & 20.8 \\
\hline Secondary & 34 & 25.4 & 34 & 39.2 & 42 & 22.0 & 169 & 30.1 \\
\hline Certificate & 2 & 1.5 & 1 & 0.4 & 0 & 0.0 & 3 & 0.5 \\
\hline Diploma & 0 & 0.0 & 2 & 0.8 & 0 & 0.0 & 2 & 0.4 \\
\hline Graduate & 1 & 0.7 & 0 & 0.0 & 1 & 0.5 & 2 & 0.4 \\
\hline \multicolumn{9}{|l|}{ Marital Status } \\
\hline Single & 18 & 13.4 & 49 & 20.7 & 24 & 12.6 & 91 & 16.7 \\
\hline Married & 116 & 86.6 & 188 & 79.3 & 167 & 87.4 & 471 & 83.3 \\
\hline \multicolumn{9}{|c|}{ Number of years of experience in tomato farming } \\
\hline$<=5$ & 33 & 24.6 & 56 & 23.7 & 36 & 18.9 & 125 & 22.2 \\
\hline $6-25$ & 80 & 59.7 & 156 & 67.8 & 149 & 78.0 & 385 & 68.5 \\
\hline $26-45$ & 21 & 15.7 & 24 & 10.1 & 6 & 3.1 & 51 & 9.1 \\
\hline$>45$ & 0 & 0.0 & 1 & 0.4 & 0 & 0.0 & 1 & 0.2 \\
\hline \multicolumn{9}{|l|}{ Household Size } \\
\hline$<=3$ & 24 & 17.9 & 74 & 31.2 & 16 & 8.4 & 114 & 20.3 \\
\hline $4-6$ & 76 & 56.7 & 87 & 36.7 & 127 & 66.5 & 290 & 51.6 \\
\hline $7-9$ & 26 & 19.4 & 60 & 25.3 & 42 & 22.0 & 128 & 22.8 \\
\hline$>9$ & 8 & 6.0 & 16 & 6.8 & 6 & 3.1 & 30 & 5.3 \\
\hline \multicolumn{9}{|l|}{ Age of dependents } \\
\hline$<15$ & 276 & 50.4 & 383 & 32.1 & 368 & 38.1 & 1027 & 38.0 \\
\hline $15-65$ & 268 & 48.9 & 763 & 64.0 & 5722 & 59.3 & 1603 & 59.2 \\
\hline$>65$ & 4 & 0.7 & 46 & 3.9 & 5 & 2.6 & 75 & 2.8 \\
\hline Total & 548 & & 1192 & & 965 & & 2705 & \\
\hline Dependency Ratio & & 104.5 & & 56.3 & & 68.6 & & 68.9 \\
\hline
\end{tabular}

Source: Field Survey, 2015

Besides this, it is claimed that since women have limited experience in the market economy, they tend to be cautious in their choice of business undertakings in order to avoid possible failures (Sharma and Zeller, 2000). These possible business failures which have become a constant and prominent feature of the tomato industry in Ghana (Donkoh et al., 2013), are likely to be higher for females than for males, given pervasive gender inequalities. The male dominance could also be explained by the fact that in most African societies with Ghana being no exception, males are the decision makers and usually traditional owners of land and have easier access to land for farming (Kame ri-Mbote, 2005). In relating this to the capacity to save among the respondents, it can be conjectured that all things being equal, in Ghana as far as tomato production is concerned, males hold sway in terms of income from this sector of agricultural production. Hence, males are more likely to have higher savings capacity in the tomato sector than their female counterparts (Aidoo-Mensah, 2017).
The age distribution of the respondents indicates a mean age of 39.90 years with the modal age group being $30-65$ years. There is therefore compelling evidence that there is potential for savings mobilisation from the tomato sector in Ghana since majority of these respondents are in their middle ages where according to the life cycle hypothesis savings are positive (Modigliani and Brumberg, 1954; Ando and Modigliani, 1963).

Education has been described as the process of acquiring knowledge, values, skills and attitudes in order to enable an individual develop his/her capacities for general well-being (Aidoo-Mensah, 2017). It has been observed to affect the level of discretion an individual employee while making purchases. Thus, the more educated a person is, the higher the level of discretion, it is assumed that individual will employ in making purchases (Pratap, 2017). This implies that an educated customer would weigh his options carefully before going for a purchase. Education is therefore, regarded as important determinant of savings habits as it equips one 
with the required knowledge in the discretional use of one's income (Donkoh, Tachega and Amowine, 2013), thereby positively influencing one's ability to accumulate assets - savings (Avery and Kennickell, 1991; Browning and Lusardi, 1996).

Table 2 indicates that the Upper East Region has the highest level of respondents with no formal level of education (38.2\%) as compared to $22.4 \%$ in the Ashanti Region and $16.5 \%$ in the Brong Ahafo Region. The gap in the educational attainment between the Upper East Region and the country as a whole is still very wide. The relatively low level of education in the region has been attributed not only to general poverty and cultural practices but also to the very late introduction of education into the region (GSS, 2013) and this is more likely to have a negative effect on their income levels, vis-à-vis, and their savings levels (Aidoo-Mensah, 2017).

Research indicates that marriage has a large effect on reducing the risk of poverty and is associated with a higher probability of attaining affluence over the life course when compared with non-marriage (Aidoo-Mensah, 2017). Compared to married couples, unmarried people have also been found to save much lower portions of their income and accumulate fewer assets (Grinstein-Weiss, Zhan and Sherraden, 2004). Therefore, from an economic perspective, marriage has several characteristics that may enhance wealth accumulation (Waite, 1995) and also brings in its trail an array of benefits (Waite and Gallagher, 2000) of which savings is key.

Table 2 indicates that $83.3 \%$ of all the respondents were married. Marital status across the three regions of the study indicates that over $70 \%$ of the respondents are married in each region. It is most likely that majority of the farmers are married in order to get extra hands to assist them in their farm operations (Aidoo-Mensah, 2017).

Much as it is true that marriage may play an important role in wealth accumulation, the reality of this assertion depends very much on the contribution each member of the marital union makes to the household wealth (AidooMensah, 2017). This is because the total product of a married couple, provided both are engaged in income generation activities, is larger than the sum of the output of each produced separately (Grinstein-Weiss, Zhan and Sherraden, 2004). Of the 471 married respondents, about $88 \%$ indicated that their spouses were engaged in some form of income generating activities as seen on Table 3. It can therefore be inferred that all things being equal, this $88 \%$ (412) whose spouses were engaged in some form of income generating activities are more likely to have higher income levels, hence, higher savings capacity than their counterparts (13\%) (Aidoo-Mensah, 2017).

Table 3: Distribution of Income Generating Status of Spouses of Respondents

\begin{tabular}{lll}
\hline Income Generating Status of Spouse & $\mathrm{N}$ & $\%$ \\
\hline $\begin{array}{l}\text { Spouse is not engaged in income } \\
\text { generation }\end{array}$ & 59 & 12.5 \\
$\begin{array}{l}\text { Spouse is engaged in income } \\
\text { generation activities }\end{array}$ & 412 & 87.5 \\
$\quad$ Total & 471 & 100.0 \\
\hline Source: Field Survey, 2015 & &
\end{tabular}

Source: Field Survey, 2015
The idea of the importance of years of experience in farming is consistent with the widely held notion that considerable years of experience in farming helps the farmer to adapt to the risks of farming (Boggess et al., 1985). This implies that an increase in the number of years in farming will increase farm productivity because farmers will gain more skills in the performance of farm operations (Maliwichi, Pfumayaramba and Katlego, 2014). Moreover, this may lead to reduction in the use of financial reserves as the increased skills of the farmers allow them to adapt to the risky and uncertain environment in which the farming activities operate (Boggess $\boldsymbol{e t}$ al., 1985).

Table 2 indicates that $68.5 \%$ of all the respondents have 6-25 years of experience in tomato farming. This implies that majority of the tomato farmers have considerable length of experience in tomato farming and therefore would be conversant with constraints to tomato production, thereby increasing their chances of circumventing these constraints in order to increase their tomato production (Al-Shadiadeh et al., 2012). This could increase their level of income which is likely to reflect on the volume of their financial savings (AidooMensah, 2017).

Household size is seen as an important economic indicator which highlights the notion of dependency ratio. The dependency ratio tends to serve as a relationship between the population aged 0-14 years and 65 years and above to the working-age population (15-64 years old). This ratio gives an indication of the pressure a household or an individual may experience as a result of supporting economically dependent ones. This is for the reason that a high dependency ratio underscores the economic liability imposed on working members of a household due to the economic support such members offer to children and older household members who are often economically dependent.

The overall dependency ratio of the respondents as indicated on Table 2 is $68.9 \%$. This is however lower than the national age dependency ratio of $73.43 \%$ which was last measured in 2014.

According to Amaza et al., (2009), a large household size offers farmers ample availability of labour pool for farm operations. Nevertheless, a large family size has the unpleasant possibility of bringing in its trail greater risk of poverty, chronic food insecurity and child malnutrition (Maxwell, 1996). This is particularly true when most of the household members are economically dependent on the working members of the household.

Table 2 indicates that $51.6 \%$ of all the respondents have household size of 4-6 persons. Surprisingly, all the regions have their highest household size within this household size bracket. The Upper East Region has the highest proportion of $66.5 \%$ within this household size bracket, followed by the Ashanti Region (56.7\%) and the Brong Ahafo Region (36.7\%).

The agricultural sector in most developing countries has been observed to be dominated by smallholder farmers whose agricultural activities though done on small scale are responsible for the production of most of the crop and livestock products (Salami, Kamara and Brixiova, 2010). In Ghana, the pattern of tomato production does not 
differ from other agricultural ventures in which farmers make use of small holdings. The underlying reasons for small farm holdings in tomato production in particular have been attributed to the fact that land preparation and other cultural practices are mainly carried out manually (Aidoo-Mensah, 2018). From Table 4, it can be seen that the average farm size for the pooled sample is 1.30 hectares (ha) which is below the national average area of production of 2.0 ha per farmer per year for tomato cultivation (Adu-Dapaah and Oppong-Konadu, 2002).

Table 4: Means and standard deviations of respondents' farm sizes (Hectares) by locations

\begin{tabular}{lllll}
\hline Region & Minimum & Maximum & Mean & $\begin{array}{l}\text { Std } \\
\text { deviation }\end{array}$ \\
\hline $\begin{array}{l}\text { Ashanti } \\
\begin{array}{l}\text { Region } \\
(\mathrm{N}=134)\end{array}\end{array}$ & 0.50 & 5.00 & 1.77 & 0.98 \\
$\begin{array}{l}\text { Brong Ahafo } \\
\text { Region } \\
(\mathrm{N}=237)\end{array}$ & 0.40 & 7.00 & 1.28 & 0.67 \\
$\begin{array}{l}\text { Upper East } \\
\text { Region } \\
(\mathrm{N}=191)\end{array}$ & 0.30 & 6.00 & 0.99 & 0.60 \\
$\begin{array}{l}\text { All } \\
\text { households } \\
(\mathrm{N}=562)\end{array}$ & 0.30 & 7.00 & 1.30 & 0.87 \\
\hline $\begin{array}{l}\text { Source: Field Survey, 2015 } \\
\text { (n) }\end{array}$ & & & \\
\hline
\end{tabular}

\section{Empirical Characteristics of Respondents' Savings Behaviour \\ Diagnostic Statistics}

Table 5 indicates that the F-statistics for all the 4 models were significant at the $1 \%$ level implying that the predictors as a group were important determinants of the pooled savings of the respondents. On the basis of the $\mathrm{R}^{2}$ statistics, the two Keynesian models give a better fit. However, all the four models explain a relatively larger proportion of variations in savings for the respondents.

Table 5: Diagnostic Statistics

\begin{tabular}{llll}
\hline MODEL & $\mathrm{R}^{2}$ & $\mathrm{~F}$-statistic & $\mathrm{p}$-value \\
\hline Model 1 & 0.857 & $\mathrm{~F}(12,546)=273.616$ & $\mathrm{p}<.001$ \\
Model 2 & 0.925 & $\mathrm{~F}(12,546)=546.349$ & $\mathrm{p}<.001$ \\
Model 3 & 0.853 & $\mathrm{~F}(12,546)=263.116$ & $\mathrm{p}<.001$ \\
Model 4 & 0.833 & $\mathrm{~F}(12,546)=227.722$ & $\mathrm{p}<.001$ \\
\hline
\end{tabular}

Source: Field Survey, 2015

\section{Income}

From Table 6, Model 1 (Absolute Income Hypothesis) which is the linear savings function propounded by Keynes indicates that the Marginal Propensity to Save (MPS), that is, the coefficient of the income is 0.884 . The positive sign of income is consistent with a priori expectation and it is also significantly different from zero at the $1 \%$ level of probability. The MPS of 0.884 implies that for every GH $\propto 1$ increase in income, the respondents are likely to save about $\mathrm{GH} \phi 0.88$ of this $\mathrm{GH} \phi 1$, giving an MPS of $88 \%$. Burney and Khan (1992), similarly, found a considerably high MPS among rural households in Pakistan, but (Guma and Bonga-Bonga, 2016) found that a $100 \%$ change in GDP growth resul ted in a relatively low MPS of 3\% among households in South Africa.
The absolute income hypothesis is a short run theory and makes the assumption that marginal propensity to consume (MPC) is between zero and one. MPC declines with increase in income, implying that marginal propensity to save increases as income increases (Mbuthia, 2011). The implication of this assertion that MPS increases with increase in income becomes more apparent in developing countries where income plays an important role in determining household savings as the ability to save depends largely on having more than enough income to take care of basic household needs (Carpenter and Jensen, 2002). In most instances among rural households, as the income increases, the increment is partly consumed and partly saved for purposes of financial security in periods of poor harvest, unemployment, illness, death of bread-winner or for investment so as to enhance future income (Mbuthia, 2011). Moreover, since rural activities are predominantly agrarian in nature with high level of uncertainty, it tends to exert a powerful influence on their savings behaviour such that these households become more risk-averse and tend to save more for the rainy day (Burney and Khan, 1992).

It is therefore not surprising that the MPS of the respondents is relatively high because of the need to take their destiny particularly in the areas of saving for their social security and the provision of finance for their production activities, into their own hands. These respondents who are mainly tomato farmers and who find themselves in the informal sector of the economy in most cases depend on the informal financial sector for their financial needs especially credit to beef up their production activities. However, because of the small size of the resources the informal financial sector controls, it is hardly able to satisfy the credit needs of its beneficiaries. On the other hand, the formal financial sector which is relatively well resourced and in a better position to meet the credit needs of such credit seekers like the respondents scarcely seem to come to their aid, because of difficulties in loan administration, high transaction costs and risk of default (Osei, 2011). Moreover, farmers by nature of the financial weaknesses are unable to access credit facilities from the formal financial institutions due to their lack of requisite collateral security to buttress their credit application (Adu-Dapaah and Oppong-Konadu, 2002). Under such circumstances, actors in the informal sector like the respondents (tomato farmers) have to build their own capital from their savings for the acquisition and employment of complementary production inputs and for the adoption of improved technologies for their production activities.

\section{Farm Size}

Model 1 also indicates a significant but negative relationship between farm size and savings. This result is contrary to the findings of Osondu et al., (2015), whose work among farm households in Anambra State, Nigeria, found a positive and significant relationship between amounts saved using informal means by female headed farms households and farm size.

Though the negative sign is contrary to a priori expectation, it sounds plausible as large scale farms as part of their expansion strategies have been found to invest in such high-end inputs as certified seeds, fertilizers and 
adoption of better agronomic practices (Mburu et $\boldsymbol{a l}$., 2014). It is therefore envisaged that the investment of funds as part of expansion strategies by large farms may invariably reduce the amount that can be saved particularly in the short run (Osondu et al., 2015).

However, when the relationship between savings and farm size is considered from the productivity point of view, the inverse relationship given by Model 1 may be justified. In agricultural production inverse relationship is a stylized fact which corroborates negative connections between farm size and its corresponding productivity. It means that with the increase in farm size output per unit (that is, per acre or hectare) of land decreases (Mahmood et al., 2014). If this happens to be the case, then income per unit of land would decrease as productivity decreases, hence, savings would all things being equal fall as well.

\section{Proximity to the financial service provider}

As seen on Table 6, all the models indicate a significant but negative relationship between savings and proximity to the financial service provider. The result is contrary to the findings of Kiiza and Pederson (2002) who found a positive and significant relationship between the level of net savings deposits and proximity of financial institution to households in a study on savings mobilisation in Uganda.
The negative sign is contrary to a priori expectation in that proximity to the financial service provider has been posited as one of the factors that would influence households' use of the service of financial intermediaries for savings as shorter geographical distance to the financial institution or the premises of the financial intermediary is deemed vital in cutting down transaction costs for savers (Akaah et al., 1987; Wright, 1999; Bendig et al., 2009). In spite of this assertion the negative sign is still important particularly in rural areas of developing countries where social ties and the web of extended family obligations demand that prosperous family members share their wealth with their kinsmen (Akaah et al., 1987). As a consequence, in order to avoid undue interference from family members, most wealthy savers would want to transact their financial dealings with financial institutions at relatively long geographical distances from their communities where their relatives may not see them.

\section{Secondary Earners and the amount they contribute to household income}

Model 2 indicates a significant (at the 10\%) but negative relationship between savings and the number of secondary earners and the amount contributed by these secondary earners.

Table 6: Ordinary Least Squares Estimates of the Savings Functions for the Respondents' Savings Behaviour

\begin{tabular}{|c|c|c|c|c|c|c|c|c|}
\hline Variables & $\begin{array}{l}\text { Model } 1 \\
\mathrm{R}^{2}=0.857 \\
\mathrm{~F}=0.00 \\
\text { Coefficient }\end{array}$ & $\mathrm{P}$-value & $\begin{array}{l}\text { Model } 2 \\
\mathrm{R}^{2}=0.925 \\
\mathrm{~F}=0.00 \\
\text { Coefficient }\end{array}$ & $\mathrm{P}$-value & $\begin{array}{l}\text { Model } 3 \\
\mathrm{R}^{2}=0.853 \\
\mathrm{~F}=0.00 \\
\text { Coefficient }\end{array}$ & $\mathrm{P}$-value & $\begin{array}{l}\text { Model } 4 \\
\mathrm{R}^{2}=0.833 \\
\mathrm{~F}=0.00 \\
\text { Coefficient }\end{array}$ & $\mathrm{P}$-value \\
\hline (Constant) & -2962. & 0.000 & 97.6 & 0.000 & -1164.5 & 0.000 & -604.9 & 0.000 \\
\hline Gender & 32.286 & 0.584 & -.015 & .993 & 2.349 & 0.340 & 2.822 & 0.281 \\
\hline Marital status & 72.628 & 0.305 & 2.736 & .193 & 1.728 & 0.558 & 1.522 & 0.627 \\
\hline $\begin{array}{l}\text { Engagement in } \\
\text { non-farm } \\
\text { activities }\end{array}$ & -111.795 & 0.104 & -0.137 & 0.937 & 14.046 & $0.000 * * *$ & 14.007 & $0.000 * * *$ \\
\hline $\begin{array}{l}\text { Years of } \\
\text { education }\end{array}$ & 4.795 & 0.267 & 0.122 & .341 & .059 & .743 & 0.077 & 0.689 \\
\hline $\begin{array}{l}\text { Years of } \\
\text { tomato farming } \\
\text { experience }\end{array}$ & 3.134 & .344 & .037 & .708 & -.072 & .601 & -0.062 & 0.671 \\
\hline Income & .884 & $.000 * * *$ & & & & & & \\
\hline $\begin{array}{l}\text { Inverse of } \\
\text { income }\end{array}$ & & & -348722.6 & $.000 * * *$ & & & & \\
\hline Log of income & & & & & 318.622 & $.000 * * *$ & & \\
\hline $\begin{array}{l}\text { Log income } \\
\text { squared }\end{array}$ & & & & & & & 45.3 & $.000 * * *$ \\
\hline Farm Size & -51.99 & $.06 *$ & -1.216 & .137 & -1.55 & .180 & -1.309 & 0.286 \\
\hline Household Size & -1.276 & .911 & .002 & .995 & .262 & .580 & 0.252 & 0.616 \\
\hline $\begin{array}{l}\text { Secondary } \\
\text { Earners }\end{array}$ & -37.425 & .136 & -1.301 & $.081 *$ & -.843 & .421 & -0.65 & 0.559 \\
\hline $\begin{array}{l}\text { Contribution } \\
\text { by secondary } \\
\text { earners }\end{array}$ & -.092 & .164 & -.004 & $.070^{*}$ & -.001 & .616 & -0.001 & 0.685 \\
\hline Proximity & -17.506 & $.000 * * *$ & -.355 & $.000 * * *$ & -.555 & $.000 * * *$ & -0.565 & $.000 * * *$ \\
\hline Age & -3.421 & .240 & -.077 & .371 & -.071 & .559 & -0.085 & 0.508 \\
\hline
\end{tabular}

Source: Field Survey, $2015 * * *$ significant at 1\%,**significant at 5\%, *significant at 10\%

This finding is contrary to results of many empirical studies in developing countries which have indicated a positive and significant relationship between household savings and remittances such as the work by Brown and Foster (1994) in Tonga and Samoa which found that remittances make a significant contribution to savings of 
households on the island. Moreover, according to the permanent income hypothesis (Friedman, 1957) which draws a distinction between components of income permanent and transitory incomes, households mainly spend out of permanent income whilst transitory income of which remittances form a part, is channelled into savings.

Secondary earners are family members who contribute to household income in the form of remittances. In essence, this finding is a reflection of an important aspect of social networks particularly among rural households which the study has termed as social diversification whereby households/individuals may prefer to depend not only on their own income but on remittances from family members who might have migrated from the household. This implies that economic development among the communities of the respondents is shaped by the networks of financial interactions and dependence that exist among them (Udry and Conley, 2004). In other words, strong family and social ties seem to make it less necessary for one to depend only on his/her personal savings for economic survival but also on remittances which in most cases appear to influence the timing of household savings within the life-cycle of an individual or household especially when dis-saving sets in (Spio and Groenewald, 1996; Bendig et al., 2009). It can therefore be inferred that among the respondents, one does not only depend on his/her savings for economic survival but also on the financial assistance received from working family members who are termed as secondary earners.

\section{Engagement in non-farm activities}

Models 3 and 4 indicate a positive and significant relationship between savings and engagement in non-farm activities and this is consistent with a priori expectation. This is in line with the findings of many empirical studies in which it has been observed that in many places in Africa, engagement in non-farm activities tends to be a form of income diversification. This invariably serves as a major source of savings for farm households for food purchase in difficult times (Reardon, 1997; Gordon and Craig, 2001).

For instance, Model 3 indicates that engagement of non-farm activities would increase savings by about GH 14.05 . This suggests that non-farm activities have become an essential component of livelihood strategies among rural households in many development countries (Babat unde and Qaim, 2009) and most importantly it has been found to be positively correlated with income therefore offers a pathway out of poverty if it can be seized by the rural poor (Barrett et al., 2001).

The main driving forces for the observed trend of diversification into non-farm activities by rural households have been the declining farm incomes and the desire to insure against agricultural production and market risks (Babatunde and Qaim, 2009). In Ghana, the import of diversification into non-farm income generating activities among tomato farmers has become more apparent due to the decline in the ability of the industry to sustain farmers' livelihood. This is mainly as a result of the fact that the production of the crop is confined to only few months of the year and also largely under rain-fed conditions resulting in glut at the time of harvest, hence, low producer prices even sometimes total cost of production exceeding income realized (Adu-Dapaah and Oppong-Konadu, 2002).

\section{Equalization of income distribution}

Models 2 and 3 according to Burney and Khan (1992) have important implications for income distribution policies. In particular, a positive and statistically significant coefficient $\beta_{1}$, that is, the coefficient of the log income $(\log Y)$ of Model 3 would support the traditional Keynesian hypothesis that the equalization of income distribution increases aggregate consumption, and hence, reduces savings. The sign of the coefficient of the inverse of income, that is, $\beta_{1}$ of Model 2 can be either positive or negative depending on the shape of the savings function. In general, however, it is found to be negative (Burney and Khan, 1992) which is correctly specified by the results of the study.

Equalization of income distribution which is achieved through income re-distribution is an economic practice which basically aims at addressing the widening economic disparity between the rich and the poor (Todaro, 1997) by levelling the distribution of income or wealth among a population through direct or indirect transfer of income usually from the rich to the poor. Income re-distribution effort is generally justified on the grounds that it is an important means of lessening income inequality in a society particularly the gap between the rich and the poor and also to eliminate or reduce poverty in the society (Chetty et al., 2012)

Contrary to Keynes' assertion that the equalization of income distribution tends to increase aggregate consumption particularly among those at the lower end of the economic ladder, and hence, reduces savings, the MPS of the respondents as given by Model 1 is relatively high (about $88 \%$ ). This contradiction is best explained by the permanent income hypothesis which was formulated by Friedman (1957) as his challenge to the traditional Keynesian consumption theory. The central theme of Friedman's hypothesis is that consumption is based on what people consider as their "normal" income, which leads to an attempt to maintain a fairly constant standard of living even when incomes vary from period to period. Therefore, increases (and decreases) in income have little effect on consumption as people deem the increase in income as temporary, hence, the urge to save more in anticipation that future incomes may decrease significantly. The expectations of future income according to Friedman depend largely on what has happened in the past.

If this is the case, then it makes economic sense for the respondents to consume less of their present income in order to make room to save more since the performance of the tomato industry in Ghana for the past few years has not been encouraging. This is consistent with the assertion of Robinson and Kolavalli (2010) that the tomato sector in Ghana has failed to reach its potential, in terms of attaining yields comparable to other countries, in terms of the industry's ability to sustain processing plants, and in terms of improving the livelihoods of those households involved in its production. Furthermore, because of the seasonal nature of the tomato industry, the respondents receive a 
large part of their incomes only once or twice a year, whereas their expenditure is continuous. Such a cash-flow pattern usually results in periods of deficits and surpluses, thus, in order to survive the periods of deficits, they have to save more of their income (Desai, 1983).

Moreover, looking at the incidence of the relatively high MPS (about 88\%) among the respondents, it can be inferred that saving/consumption decisions among the respondents, rest not only on the levels and variance of their income which is linked to changes in their production. However, their saving/consumption decisions also take into consideration the absence of suitable credit and insurance markets to take their peculiar situation into consideration (Aryeetey and Udry, 2000). Not only that but also these are people who do not receive public pension payments as they work outside the formal sector (Bendig et al., 2009). Hence, the need to take their future into their own hands by saving high proportions of their incomes in expectation that future incomes will decrease significantly especially in their old age as predicted by the both the permanent income hypothesis and the life cycle hypothesis. Both theories assume that households have a perfect vision of their future income flows, their consumption levels as well as their lifespan and therefore behave rationally with self-control in order to save towards their retirement (Mbuthia, 2011).

Beside all these, according to Cooke et al., 2016, a recent IMF paper on income inequality and fiscal policy, categorized Ghana as having one of the fastest increasing inequality levels in Africa. This is in spite of such programmes as the Livelihood Empowerment Against Poverty (LEAP) cash transfer aimed at reducing the level of inequality in Ghana. This to a large extent implies that the respondents cannot rely on government's social intervention efforts to limit growth in income inequality, support the provision of public services as well as foster economic growth in their communities and must therefore rely on their own initiative by cutting down consumption in order to save to take care of their future. The decision of cutting down consumption in order to save in the face of income inequality gives credence to the assertion by Loayza et al., (2000) that income inequality is an important determinant of saving and that it played a prominent role in post-Keynesian models of savings and growth (Kaldor, 1957; Pasinetti, 1962).

\section{Non-linearity of savings and income}

According to Burney and Khan (1992), a positive and statistically significant coefficient, $\beta_{1}$ of the $\log$ squared income of Model 4 would support the hypothesis of nonlinear relationship between savings and income and this is correctly specified by the results of the study. This suggests that among the respondents, the hypothesis of non-linear relationship between savings and income holds. In other words, a change in income (a decrease or an increase) may not always bring about an equal or proportional change in savings.

In the view of Burney and Khan (1992), this hypothesis of non-linearity between savings and income may be explained in part by the level of uncertainty surrounding income particularly at the rural household level. This is because rural income generating activities are basically agrarian in nature and the income derived from agriculture and its related activities are inherently uncertain. The uncertainty surrounding the rural income poses not only a real threat to their consumption levels but is also more likely to exert a powerful influence on their savings behaviour. Thus, rural dwellers who in most cases have been observed to be risk-averse due to high level of poverty among them, have been observed to consume less of an increase in income in order to save more for the "rainy day" (Burney and Khan, 1992; AlvarezCuadrado and Vilalta, 2012).

\section{CONCLUSIONS AND RECOMMENDATIONS}

The study was motivated by the fact that it is important to understand that rural households more especially farmers can play an essential role in providing voluntary savings for capital formation, vis-á-vis, and economic development which in some cases can significantly reduce the volume of external credit lent to them at usurious interest rates. Thus, the need for accurate analysis of the savings behaviour of these farmers in order to gain thorough knowledge of the determinants of their savings behaviour as a means of enacting appropriate policies to tap into savings pool at the rural level for national development. In essence, the need to achieve substantial and sustainable rural development by means of household savings requires creating a synergy between rural households and researchers on one hand and researchers and policy makers on the other hand.

The following specific findings among others were made: The study indicated a significant but negative relationship between farm size and savings. Though the negative sign is contrary to a priori expectation, it sounds plausible since expanding farm size requires more investment of funds which is more likely to reduce the amount saved particularly in the short run.

The study showed a significant but negative relationship between savings and proximity to the financial service provider. Though the negative sign is contrary to a priori expectation, it gives an indication that in order to avoid undue interference from family members, mostly wealthy savers would want to transact their financial dealings with financial institutions at relatively long geographical distances from their communities where their relatives may not see them.

Negative but significant relationship was established between savings and the number of secondary earners and the amount contributed by these secondary earners. In essence, this finding is a reflection of an important aspect of social networks particularly among rural households which the study has termed as social diversification whereby households/individuals may prefer to depend not only on their own income but income from other income earners within their households. In other words, strong family and social ties seem to make it less necessary for one to depend only on his/her personal savings for economic survival. Thus, it can be inferred that among the respondents, one does not only depend on his/her savings for economic survival but also on the financial assistance received from working family members who are termed as secondary earners. 
Engagement in non-farm activities positively and significantly influenced savings. This suggests that nonfarm activities have become an essential component of livelihood strategies among rural households in most developed countries.

Contrary to Keynes' assertion that the equalization of income distribution increases aggregate consumption, and hence, reduces savings, the study found the opposite to be the case, that is, the MPS of the respondents was relatively high (about $88 \%$ ).

The study also established the hypothesis of nonlinearity between savings and income among the respondents. This implies that due to uncertainty surrounding rural incomes, rural dwellers may tend to consume less of an increase in income in order to save more for the "rainy day".

It has long been recognised that household size has serious implications for a nation's labour supply, savings rates and capital formation, all of which can shape and influence the nation's economic growth. Though, relatively smaller as well as larger household sizes have their consequential socio-economic implications for a nations' well-being, it is however, obvious that the negative repercussions of relatively larger household sizes override their supposed benefits. The negative effects of the household size on household income, vis-à-vis, and savings may become more pronounced when there is an increase in the number of household members below age 16 who are not income earners and therefore have to depend on others. In the same way, the low income and savings associated with relatively larger household size may be compounded by an increase in the number of household members above 65 years, that is, those on retirement. All things being equal, a household with few dependents can devote a smaller share of its income on supporting these dependents and can therefore save more. It is therefore recommended that as part of agricultural extension activities, education on population issues and its implications for development is passed on to farmers. Moreover, it is recommended that the government through the Ministry of Health will intensify the support given to family planning programmes to ensure that population growth rates and household sizes are reduced to promote higher levels of household savings. In addition, knowledge on national population policy could be included in the curriculum of schools for an early appreciation and understanding of population issues and its effect by the younger ones.

Economic growth and development have been observed to be strongly correlated with poverty alleviation. Meanwhile, it is agreed that one of the key ingredients to economic growth and development lies in access to financial services particularly among rural households. The study indicated a relatively high marginal propensity to save of about $88 \%$ among the respondents which is an indication of their capacity and potential to save. This finding makes a convincing case for financial intermediaries to extend the needed financial services to rural households. Such an approach of extending the needed financial services to the rural households may result in two-pronged opportunities; one, to the rural households who may be set on the pathway to economic growth and development and two, to the financial intermediaries in their quest for savings mobilisation and its subsequent investment into crucial sectors of the economy.

\section{REFERENCES}

ABDELKHALEK, T., ARESTOFF, F., DE FREITAS, N. M., \& MAGE, S. (2010). A microeconometric analysis of households saving determinants in Morocco. African Review of Money Finance and Banking, 7-27. https://www.jstor.org/stable/41803204?seq=1/analyze ADU-DAPAAH, H. K. \& OPPONG-KONADU, E. Y. (2002). Tomato production in four major tomato-growing districts in Ghana: Farming practices and production constraints. Ghana Journal of Agricultural Science, 35, 11-22.DOI: http://dx.doi.org/10.4314/gjas.v35i1.1840

AIDOO-MENSAH, D. (2017). Economic analyses of savings behaviour of tomato farmers in Ghana. (Unpublished doctoral thesis). Kwame Nkrumah University of Science and Technology, Ghana.

AIDOO-MENSAH, D. (2018). Determinants of income patterns of tomato farmers in Ghana. Review of Agricultural and Applied Economics, 21 (2) 58-70, DOI: $\underline{10.15414 / \text { raae.2018.21.02.58-70 }}$

AKAAH, I., DADZIE, K., \& DUNSON, B. (1987). Formal financial institutions as savings mobilizing conduits in rural LDCs: an empirical assessment based on the bank savings behavior of Ghanaian farm households. Savings and Development. https://www.jstor.org/stable/25830104?seq=1\#page_scan tab_contents

ALAMGIR, M. (1976). Rural savings and investment in developing countries: Some conceptual and empirical issues. The Bangladesh Development Studies, 4(1), 1-48. https://www.jstor.org/stable/40794117?seq=1\#page_scan tab contents

AL-SHADIADEH, A. N., AL-MOHAMMADY, F. M., \& ABU-ZAHRAH, T. R, (2012). Factors influencing adoption of protected tomato farming practices among farmers in Jordan Valley. World Applied Sciences Journal 17 (5): 572-578.

ALVAREZ-CUADRADO, F., \& VILALTA, E. M. (2012). Income inequality and saving. Discussion Paper Series, 7083, 2-59. DOI: 10.1111/obes.12236

AMAZA, P., ABDOULAYE, T., KWAGHE, P., \& TEGBARU, A. (2009). Changes in household food security and poverty status in PROSAB area of Southern Borno State, Nigeria. International Institute of Tropical Agriculture.

ANDO, A., \& MODIGLIANI, F. (1963). The 'life-cycle' hypothesis of saving: aggregate implications and tests. American Economic Review, 53(1), 55-84. http://www.jstor.org/stable/1817129?origin=JSTOR-pdf ARMENDARIZ, B. A., \& MORDUCH, J. (2005). Microfinance: Where do we stand? Financial Development and Economic Growth pp 135-148. https://link.springer.com/book/10.1057/9780230374270

ARTHUR, J, L. (2005). Family size and its socioeconomic implications in the Sunyani Municipality of the Brong Ahafo Region of Ghana, West Africa. (Unpublished MSc. Dissertation). University of Cape Coast. 
ARYEETEY, E., \& GOCKEL, F. (1991). Mobilizing domestic resources for capital formation in Ghana (African Economic Research Consortium, Research Paper No. 3). Nairobi, Kenya.

ARYEETEY, E., \& UDRY, C. (2000). Saving in SubSaharan Africa (Centre for International Development Working Paper No. 38). Harvard Kennedy School.

AVERY, R. and KENNICKELL, A. (1991). Household saving in the US. Review of Income and Wealth, 37(4), 409-432. DOI: https://doi.org/10.1111/j.14754991.1991.tb00381.x

BABATUNDE, R. O., \& QAIM, M. (2009). Poverty and income inequality in rural Nigeria: the role of off-farm income diversification. Germany: University of Gottingen.

BAJTELSMIT, V. L., \&VANDERHEI, J. A. (1997). Risk aversion and retirement income adequacy. In M. S. Gordon, O. S. Mitchell, and M. M. Twinney (Eds.), Positioning pensions for the twenty-first century. Philadelphia: University of Pennsylvania Press.

BARRETT, C. B., REARDON, T., \& WEBB, P. (2001). Nonfarm income diversification and household livelihood strategies in rural Africa: concepts, dynamics, and policy implications. Food Policy, 26(4), 315-331. doi.org/10.1016/S0306-9192(01)00014-8

BARTLETT, J. E., KOTRLIK, J. W., \& HIGGINS, C. H. (2001). Organizational research: determining appropriate sample size in survey research. Information Technology, Learning, and Performance Journal, 19(1)

BECK, T., DEMIRGUC-KUNT, A., \& PERIA, S. M. (2006). Banking services for everyone? barriers to bank access and use around the world (World Bank Policy Research Working Paper No. 4079). Switzerland.

BENDIG, M., GIESBERT, L., \& STEINER, S. (2009). Savings, credit and insurance: household demand for formal financial services in rural Ghana (GIGA Working Paper No. 94).

BEVERLY, S. (1997). How can the poor save? Theory and evidence on saving in low-income households (St. Louis Center for Social Development, Washington University Working Paper No. 97-3). Washington.

BEVERLY, S., \& SHERRADEN, M. (1999). Institutional determinants of saving: implications for low-income households and public policy. Journal of SocioEconomics, 28, 457-473. ㅇoi.org/10.1016/S1053$\underline{\text { 5357(99)00046-3 }}$

BOFINGER, P., \& SCHEUERMEYER, P. (2014). Income distribution and household saving. Web Source: Retrieved June 152016 from the website of Progressive Economy

www.progressiveeconomy.eu/sites/.../BofingerScheuerm eyerInequalityandSaving.pd

BOGGESS, W. G., ANAMAN, K, A., \& HANSON, G. D. (1985). Importance, causes, and management responses to farm risks: evidence from Florida and Alabama. Southern Journal of Agricultural Economics. DOI: https://doi.org/10.1017/S0081305200025103

BROWN, R. P. C., \& FOSTER, J. (1994). Remittances and savings immigrant-sending countries. Pacific Economic Bulletin Vol. 9 (2). DOI: https://doi.org/10.1177/011719689500400109
BROWNING, M., \& LUSARDI, A. (1996). Household saving: Micro theories and micro facts. Journal of Economic Literature, 34(4), 1791-1855. http://www.jstor.org/stable/2729595?origin=JSTOR-pdf BURNEY, N. A., \& KHAN, A. H. (1992). Socioeconomic characteristics and household savings: An analysis of the households" saving behaviour in Pakistan. The Pakistan Development Review, 31:1 pp. 31-48. https://www.jstor.org/stable/41259536

CANOVA, L., RATTAZZI, A. M. M., \& WEBLEY, P. (2005). The hierarchical structure of saving motives. Journal of Economic Psychology, 26(1), 21-34. DOI: https://doi.org/10.1016/j.joep.2003.08.007

CHAGOMOKA, T., DRESCHER, A., GLASER, R., MARSCHNER, B., SCHLESINGER, J., \& G NYANDORO (2015). Vegetable production, consumption and its contribution to diets along the urbanrural continuum in northern Ghana. African Journal of Food, Agriculture, Nutrition and Development, 15(4), 10352-10367.

GEDELA, S. P. R. (2012). Determinants of saving behaviour in rural and tribal households (An empirical analysis of Visakhapatnam District). International Journal of Research in Social Sciences, 2(3).

GHANA STATISTICAL SERVICE (2008). Ghana living standards survey report of the fifth round (GLSS 5).

GHANA STATISTICAL SERVICE, (2013). 2010 Population and Housing Census - District Analytical Report (Sekyere Central District).

GORDON, A., \& CRAIG, C. (2001). Rural non-farm activities and poverty alleviation in Sub-Saharan Africa. Policy Series 14. Chatham, UK: Natural Resources Institute.

GOTTSCHALCK, A. O. (2008). Net worth and the assets of households: 2002. Washington, DC: U.S. Census Bureau.

GRINSTEIN-WEISS, M., ZHAN, M., \& SHERRADEN, M. (2004). Saving performance in individual development accounts: does marital status matter? Journal of Marriage and Family, 68, 192-204. doi.org/10.1111/j.17413737.2006.00241.x

GUMA, N., \& BONGA-BONGA, L. (2016). The relationship between savings and economic growth at the disaggregated level. MPRA Paper No. 72131

HIRSCHLAND, M. (2006). Key messages from savings services for the poor. In Consultative Group to Assist the People: Poor peoples' savings: Qs and As with experts. Washington D. C.

HUSSEIN, K. A., \& Thirlwall, A. P. (1999). Explaining differences in the domestic savings ratio across Countries: A panel data study. Web Source: Retrieved February 15, 2015 from the Website of Kent University, http://kar.kent.ac.uk/id/eprint/16857

I.M.F. (2015). Gender and income inequality. Web Source: Retrieved September 16, 2015 from the website of International Monetary Fund, https://www.imf.org/external/pubs/ft/sdn/2015/sdn1520_ info.pdf.

JEROME, M. E., \& PERREAULT, D. W. Jr. (1991). Essentials of Marketing ( $\left.5^{\text {th }} \mathrm{Ed}\right)$. IRWIN Publishers.

JOHNSON, T. G. (1990). An analysis of the relationship between income distribution and socio-economic 
development conditions among communities in the Northwest Territories (Unpublished Masters dissertation). University of Saskatchewan, Canada.

KALDOR, N. (1957). A model of economic growth. Economic Journal 67(268), pp. 591-626. DOI: https://doi.org/10.2307/2227704

KAMERI-MBOTE, P. (2005). The land has its owners! Gender issues in land tenure under customary law in Kenya (IELRC Working Paper). UK: International Environmental Law Research Centre.

KAR, J., \& DASH, P. K. (2009). Formal financial services for rural small savers: a case study of Orissa, India. Annals of the University of Petroşani, Economics, 9(2), 73-82.

KATONA, G. (1975). Psychological economics. New York: Elsevier.

KELLEY, A. C., \& WILliAMSON, J. G. (1968). Household saving behavior in the developing economies: the Indonesian case. Economic Development and Cultural Change, 16(3), 385-403. DOI: https://doi.org/10.1086/450300

KEYNES, J. M. (1936). The general theory of employment, interest, and money. Palgrave Macmillan.

KIIZA, B., \& PEDERSON, G. (2002). Household financial savings mobilisation: empirical evidence from Uganda. Journal of African Economies, 10(4), 390-409. DOI: https://doi.org/10.1093/jae/10.4.390

KLAEHN, J., BRANCH, B., \& EVANS, A.C. (2002). A technical guide to savings mobilization lessons from the credit union experience. WOCCU.

KLEIN, L. R. (1954). Statistical estimation of economic relations from survey data. In L. R.

KLEIN (Ed.), Survey Methods to Economics. New York: Columbia University Press.

KODOM, M. (2013). Savings habit and use of savings among households in Ga-East Municipality. (Unpublished master thesis). University of Ghana, Legon, Accra.

KUDAISI, B. V. (2013). Savings and its determinants in West African countries. Journal of Economics and Sustainable Development, Vol.4, No.18.

LANDAU, L. (1971). Savings functions for Latin America. In H. B. Chenery (Ed.), Studies in development planning. Cambridge, Mass.: Harvard University Press.

LEFF, N. H. (1969). Dependency rates and ravings rates, The American Economic Review, 59(5), 886-896. https://www.jstor.org/stable/1810683

LOAYZA, N., SCHMIDT-HEBBEL, K., \& SER VÉN, L. (2000). Saving in developing countries: an overview. The World Bank Economic Review, 14(3), 393-414. DOI: https://doi.org/10.1093/wber/14.3.393

MAHMOOD, H. Z., KHAN, M., \& HUSNAIN, M. I. U. (2014). Re-examining the inverse relationship between farm size and productivity in Pakistan. The Journal of Animal and Plant Sciences, 24(5), 1537-1346.

MALIWICHI, L. L., PFUMAYARAMBA, T.K., \& KATLEGO, T. (2014). An analysis of constraints that affect smallholder farmers in the production of tomatoes in Ga-Mphahlele, LepelleNkumbi Municipality, Limpopo Province, South Africa. Journal of Human Ecology, 47(3): 269-274.

DOI: https://doi.org/10.1080/09709274.2014.11906761

MAXWELL, D. G. (1996).Measuring food security the frequency and severity of escaping strategies. Food
Policy, 21(3), 292-300. DOI: https://doi.org/10.1016/0306-9192(96)00005-X

MBURU, S., ACKELLO-OGUTU, C., \& MULWA, R. (2014). Analysis of economic efficiency and farm size: a case study of wheat farmers in Nakuru District, Kenya. Economics Research International. dx.doi.org/10.1155/2014/802706

MBUTHIA, A. N. (2011). Households' saving decisions in Kenya. (Unpublished doctoral thesis). The School of Economics of Kenyatta University.

MENSAH, E., KONADU, K. B., \& AGYARE, W. A. (2013). Health risk of agrochemicals usage in tomato (Lycopersicum esculentum) production in the OffinsoNorth district of Ghana. International Journal of Engineering, Science and Technology, 5(9), 1672-1681.

MIKESELL, R. F., \& ZINSER, J. E. (1973). The nature of the savings function in developing countries: a survey of the theoretical and empirical literature. Journal of Economic Literature, 11(1), 1-26.

MODERN GHANA. (2016). About regions of Ghana. Retrieved from the website of Modern Ghana,

MODIGLIANI, F., \& BRUMBERG, R. (1954). Utility analysis and the consumption function: an interpretation of cross-section data. In K. Kurihara (Ed.), Post Keynesian Economics, New Brunswick: Rutgers University Press.

NICULESCU-ARON, I. G. (2012). An empirical analysis on preferred saving instruments based on the enquiry financial situation of the Romanian households. Journal of Applied Quantitative Methods, 7(4).

OECD, (2007). Society at a glance: OECD social indicators. OECD

OSEI, R. A. (2011). Perception and utilization of financial institutions by market women in the Accra metropolis: a case of Mallam Attah market women. (Unpublished MBA dissertation) submitted to the Kwame Nkrumah University of Science and Technology, Kumasi.

OSONDU, C. K., EZEH, C. I., ANYIRO, C. O., \& BERNARD, C. L. (2015). Comparative analysis of informal savings forms of male-headed and femaleheaded farm households in Aguata local government area of Anambra State, Nigeria. Economic Engineering in Agriculture and Rural Development, 15(3), 135-143.

PASINETTI, L. (1962). Rate of profit and income distribution in relation to the rate of economic growth. Review of Economic Studies, 29:267-79. doi.org/10.2307/2296303

PEARCE, D. (1989). The feminization of poverty: women, work, and welfare. Urban and Social Change Review, 11, 28-36.

PRATAP, A. (2017). Effect of demographic factors on consumer behavior: age, sex, income and education. Web Source: Retrieved on May 24, 2017 from https://www.cheshnotes.com/2017/07/effect-of-

demographic-factors-on-consumer-behavior-age-sexincome-and-education/

REARDON, T. (1997). Using evidence of household income diversification to inform study of the rural nonfarm labor market in Africa. World Development, Vol. 25 (5), pp. 735-747. DOI: https://doi.org/10.1016/S0305750X(96)00137-4

RHA, J., MONTALTO, C., \& HANNA, S. (2006). The effect of self-control mechanisms on household saving 
behavior. Financial Counseling and Planning, 17(2), 116. Available at

SSRN:

https://ssrn.com/abstract=2232124

ROBINSON, E. J. Z., \& KOLAVALLI, S. L. (2010). The case of tomato in Ghana: Productivity. GSSP Working Paper No. 19.

ROBINSON, M. S. (2001).The microfinance revolution: sustainable finance for the poor. The International Bank for Reconstruction and Development/The World Bank. Washington, D.C.

RUTHERFORD, S. (1996). A critical typology of financial services for the poor. ActionAid and Oxfam, London.

SAINT-PIERRE, Y. (1996). Do earnings rise until retirement? Perspectives on Labour and Income, 8(2), 3236.

SALAM, A., \& KULSUM, U. (2002). Savings behaviour in India: an empirical study. The Indian Economic Journal, 50(1), 77-80.

SALAMI, A., KAMARA, A. B., \& BRIXIOVA, Z. (2010). Smallholder agriculture in East Africa: trends, constraints and opportunities. Working Papers Series No. 105, African Development Bank.

SHARMA, M., \& ZELLER, M. (2000). Factors affecting repayment rates in group-based lending: Findings from Bangladesh and Madagascar. In M. Sharma (Ed.), Microfinance: A pathway from poverty. International Food Policy Research Institute.

SINNADURAI, S. (1973). Vegetable production in Ghana. Acta Hortic. 33, 25-28. DOI: https://doi.org/10.17660/ActaHortic.1973.33.3

SNYDER, D. W. (1974). Econometric studies of household saving behaviour in developing countries: a survey. The Journal of Development Studies, 10(2), 139153. DOI: https://doi.org/10.1080/00220387408421481

SOLMON, L. C (1975). The relation between schooling and savings behavior: an example of the indirect effects of education. In: Juster, S.T. (ed.), Education, income, and human behavior, 253-294.
SPIO, K., \& GROENEWALD, J. A. (1996). Rural household savings and the life cycle hypothesis: the case of South Africa. The South African Journal of Economics, 64(4), 209-304. DOI: https://doi.org/10.1111/j.18136982.1996.tb01343.x

SUNG, J. (1997). A structural analysis of retirement funds in a family context: participation and investment in stocks. (Unpublished dissertation). The Ohio State University, Columbus, $\mathrm{OH}$.

THUNG, C. M., KAI, C. Y., NIE, F. S., CHIUN, L. W., \& TSEN, T. C. (2012). Determinants of saving behaviour among the university students in Malaysia. (Unpublished dissertation). Universiti Tunku Abdul Rahman, Malaysia. TODARO, M. P. (1997). Economic development. London: Longman

UDRY, C. R., \& CONLEY, T. G. (2004). Social networks in Ghana.

WAITE, L. J., \& GALLAGHER, M. (2000). The case for marriage. New York: Doubleday.

WAITE, L. J. (1995). Does marriage matter? Demography, 32(4), 483-507. DOI: https://doi.org/10.2307/2061670

WILSON, S. J. (2000). Demographic and institutional influences on Canadian savings behavior (Unpublished $\mathrm{PhD}$ Thesis). Queen's University, Kingston, Ontario, Canada.

WRIGHT, G. A. N. (1999). A critical review of savings services in Africa and elsewhere. MicroSave.

YEBOAH, A. K. (2011). A survey on postharvest handling, preservation and processing methods of tomato (Solanum lycopersicum) in the Dormaa and Tano South districts of the Brong Ahafo region of Ghana. (Unpublished Masters dissertation). Kwame Nkrumah University of Science and Technology.

YUH, Y., \& HANNA, S. (1997). The demand for risky assets in retirement portfolios. Proceedings of the Academy of Financial 